\title{
Industrial Contamination of Soil Related to Some Active and Closed Mine Facilities in the Republic of Macedonia
}

\author{
GORAN K. TASEV, University Goce Delcev, \\ Original scientific paper \\ Faculty of Natural and Technical Sciences, Štip, R. Macedonia UDC: 504.5:669.24/6(497.7) \\ TODOR S. SERAFIMOVSKI, University Goce Delcev, \\ Faculty of Natural and Technical Sciences, Štip, R. Macedonia
}

\begin{abstract}
Several industrial pollution sources at the territory of the Republic of Macedonia, were studied, one $\mathrm{Pb}-\mathrm{Zn}$ mine with mill, one copper mine with mill and copper leaching facility, as well as one former $\mathrm{Pb}-\mathrm{Zn}$ smelting facility near the city of Veles and one Fe-Ni smelting facility near the city of Kavadarci. The concentrations of heavy metals at Veles hot-spot were in the range: $20 \div 1823 \mathrm{mg} \mathrm{kg}^{-}$ ${ }^{\mathrm{I}} \mathrm{Pb}, 29 \div 2395 \mathrm{mg} \mathrm{kg}^{-1} \mathrm{Zn}, 28 \div 65 \mathrm{mgkg}^{-1} \mathrm{Cd}, 27 \div 82 \mathrm{mg} \mathrm{kg}^{-1} \mathrm{Cu}, 39 \div 164 \mathrm{mg} \mathrm{kg}^{-1} \mathrm{Ni}, 508 \div 938 \mathrm{mgkg}^{-1} \mathrm{Mn}$ and $1.6 \div 3.8 \% \mathrm{Fe}$, all of them being above Dutch standard optimal values. The vicinity of the Feni plant displayed concentrations of heavy metals as follows: $16 \div 31 \mathrm{mg} \mathrm{kg}^{-1} \mathrm{~Pb}, 117 \div 286 \mathrm{mgkg}^{-1} \mathrm{Zn}_{\text {, }}$

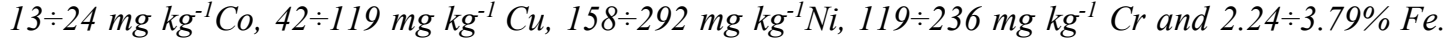
Airborne dust measurements around the Zletovo mine displayed multiplexed above standard values, with an exception of nickel, there enrichment factors ranged from mediate ones such were those for copper of 20.8, cadmium of 28.7, arsenic of 32.5 up to high ones for zinc with 341.7 and lead 925. Soil samples around the Zletovo mine displayed: $19.3-76.9 \mathrm{~g} \mathrm{~kg}^{-1} \mathrm{Fe}, 643-28000 \mathrm{mg} \mathrm{kg}^{-1} \mathrm{Mn}$, 42.3-529.66 $\mathrm{mg} \mathrm{kg-1} \mathrm{Pb}$ and $138-3240 \mathrm{mg} \mathrm{kg}^{-1} \mathrm{Zn}$. Finally around the Bucim copper mine the results displayed the following findings: $13.1 \div 225 \mathrm{mg} \mathrm{kg}^{-1} \mathrm{As}, 0.67 \div 17.9 \mathrm{mg} \mathrm{kg}^{-1} \mathrm{Cd}, 30.1 \div 171 \mathrm{mg} \mathrm{kg}^{-1} \mathrm{Cr}, 17.8 \div 1734 \mathrm{mg}$

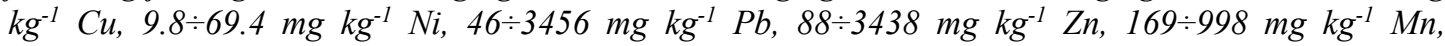
$0.73 \div 5.02 \% \mathrm{Fe}$.
\end{abstract}

Key words: heavy metals, contamination, mines, anthropogenic, $R$. Macedonia

\section{INTRODUCTION}

As major polluted localities, confirmed even with our latest results, are the areas around the former $\mathrm{Pb}$ Zn smelting plant located at the Veles city limits, active ferro-nickel plant located in the well known wine region of Kavadarci, active lead and zinc mines with their respective tailing dams in Eastern Macedonia (Zletovo) and active open pit of the Buchim copper mine with large waste dump and tailing dam (Figure $1)$.

Preventive measures are a must where mine and mine related plant are proessing and produce signficant environmental influx, so understanding the environmental impact of these processes is crucial. Metal mining has traditionally been an important part of the economy of the Republic of Macedonia and recently

Author's address: Goran Tasev, University Goce Delcev, Faculty of Natural and Technical Sciences, Štip, Krste Misirkov 10-A, R. Macedonia

Paper received: 14.05.2015.

Paper accepted: 18.05.2015. increased in importance due to governmental efforts to stimulate mining through renewed exploration and development, though the country relies on its agriculture and must safeguard its soil and water resources. Pollution from active and past mining related processing represents significant problem in some parts of the country.

The problem continuously is solved at active mines/plants while the problem is harder to solve at those with ceased production (Veles former $\mathrm{Pb}-\mathrm{Zn}$ smelting plant etc.).

\section{MATERIAL AND METHODS}

The process of sampling was carried out over a prolonged period (2004-2014). Soil surface samples (0-5 cm depth) were collected at several localities pointed earlier as potential so-called "hot spots" in regards to heavy metal pollution (Figure 1).

Samples were located using the Global Positioning System, topographic maps (1:25 000) and TrackMaker software. Each sample represents composite material collected at the central sampling point accompanied with at least four points collected around a central one within radius of $1 \mathrm{~m}$ towards N, E, S and $\mathrm{W}$ directions. 


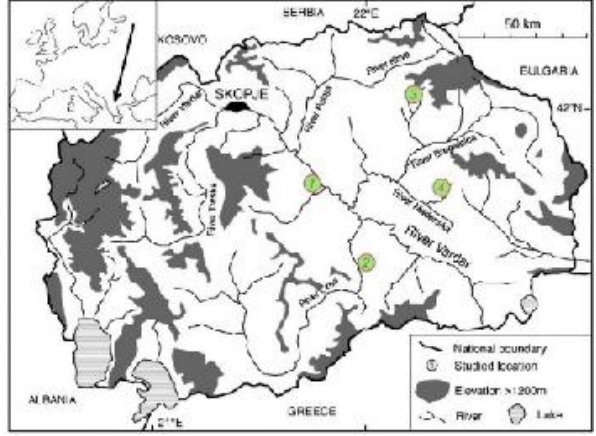

Figure 1 - Studied locations of anthopoghene pollution 1. Former $\mathrm{Pb}-\mathrm{Zn}$ smelting plant, Veles; 2. Feni smelting plant, Kavadarci; 3. Zletovo Pb-Zn mine, Probistip; 4. Buchim Cu mine, Radovis

Each sample $(\sim 0.5 \mathrm{~kg})$ was prepared for analysis and analyzed using emission spectrometry with inductively coupled plasma (ICP-AES) at the Institute of Chemistry, Faculty of Natural Sciences, University "Sts.Cyril and Methodius" Skopje, R. Macedonia. Random order of samples and standards submission to laboratory assured unbiased treatment and precision less than $5 \%$.

\subsection{Results and discussion}

The Veles smelting plant: It used to be the largest $\mathrm{Pb}-\mathrm{Zn}$ facility in former Yugoslavia with capacity for producing $65000 \mathrm{t}$ of zinc and $45000 \mathrm{t}$ of lead annually and entire production was exported.

The anthoprogenic impact in that particular part of the Veles basin has been studied at two regions

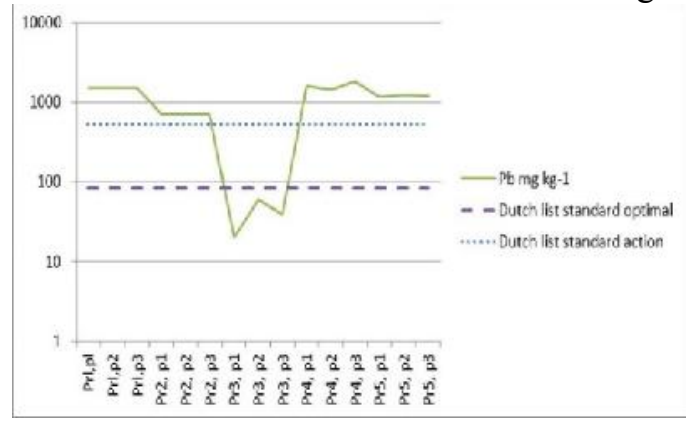

around former $\mathrm{Pb}-\mathrm{Zn}$ smelting plant during the 2008, Bashino Selo (village to the north of the smelting plant) and area to south of the smelting plant close to the city.

Within the first area were sampled two parallel sections and one section normal to them while at the second area were sampled only two parallel sections (30 $\mathrm{m}$ distances between each sample, Figure 2).

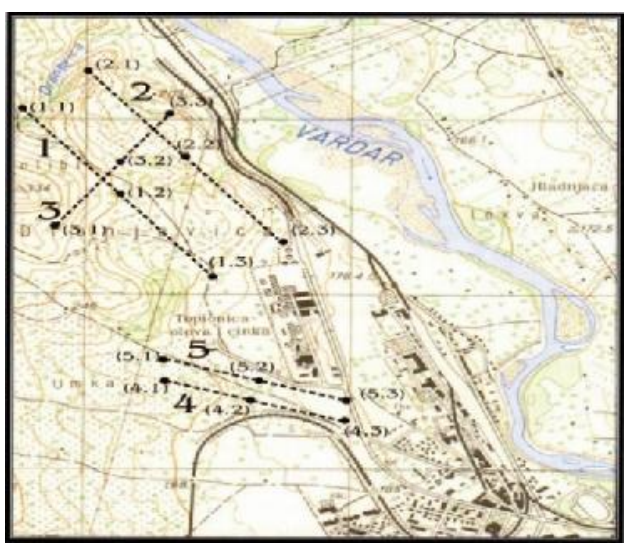

Figure 2 - Spatial distribution of profile lines and sampling points along them

Concentrations of elements were: $20 \div 1823$ $\mathrm{mg} \cdot \mathrm{kg}^{-1} \mathrm{~Pb}, 29 \div 2395 \mathrm{mg} \cdot \mathrm{kg}^{-1} \mathrm{Zn}, 28 \div 65 \mathrm{mg} \cdot \mathrm{kg}^{-1} \mathrm{Cd}$, $27 \div 82 \mathrm{mg} \cdot \mathrm{kg}^{-1} \quad \mathrm{Cu}, \quad 39 \div 164 \mathrm{mg} \cdot \mathrm{kg}^{-1} \mathrm{Ni}, \quad 508 \div 938$ $\mathrm{mg} \cdot \mathrm{kg}^{-1} \mathrm{Mn}$ and $1.6 \div 3.8 \% \mathrm{Fe}$. All of them being quite above the reference values (Table 1 and Figure 3 ).

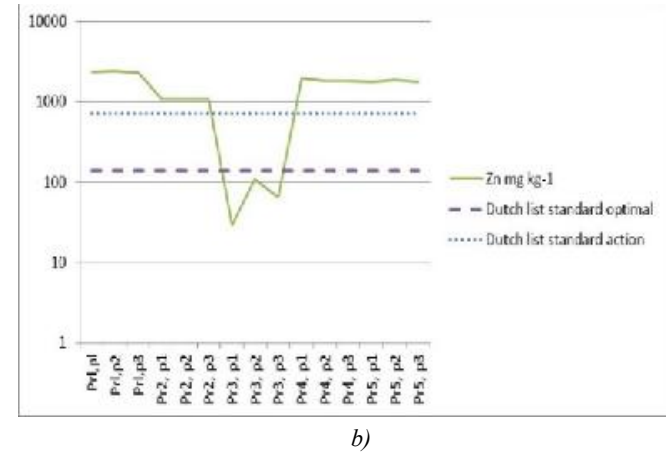

Figure 3 - Measured concentrations of Pb, Zn vs. standard values around former smelting plant near the Veles, Macedonia. (Note: Plots $a$ and $b$ have logarithmic vertical scale)

Table 1. Concentrations of metals in soil samples around the former smelting plant in the vicinity of Veles.

\begin{tabular}{|l|l|l|l|l|c|c|c|c|}
\hline Element & $\mathrm{n}$ & Median & $\min$ & $\max$ & Dutch list standard optimal & $\begin{array}{l}\text { Dutch list standard } \\
\text { action }\end{array}$ & $\begin{array}{l}\text { above } \\
\text { standard }\end{array}$ & $\begin{array}{l}\text { below } \\
\text { standard }\end{array}$ \\
\hline $\mathrm{Pb}\left(\mathrm{mg} \mathrm{kg}^{-1}\right)$ & 15 & 1190 & 20 & 1823 & 85 & 530 & 12 & 3 \\
\hline $\mathrm{Zn}\left(\mathrm{mg} \mathrm{kg}^{-1}\right)$ & 15 & 1778 & 29 & 2395 & 140 & 720 & 12 & 3 \\
\hline $\mathrm{Cd}\left(\mathrm{mg} \mathrm{kg}^{-1}\right)$ & 15 & 42 & 26 & 65 & 0,8 & 12 & 15 & 0 \\
\hline $\mathrm{Cu}\left(\mathrm{mg} \mathrm{kg}^{-1}\right)$ & 15 & 60 & 27 & 82 & 36 & 190 & 9 & 6 \\
\hline $\mathrm{Ni}\left(\mathrm{mg} \mathrm{kg}^{-1}\right)$ & 15 & 116 & 39 & 164 & 35 & 210 & 11 & 4 \\
\hline $\mathrm{Fe}(\%)$ & 15 & 3,2 & 1,6 & 3,8 & 1,8 & - & 13 & 2 \\
\hline $\mathrm{Mn}\left(\mathrm{mg} \mathrm{kg}^{-1}\right)$ & 15 & 841 & 508 & 938 & & & & \\
\hline
\end{tabular}


If an average of $\mathrm{Pb}$ in World soils is $35 \mathrm{mg} \mathrm{kg}^{-1}$ [1], in European topsoil $33 \mathrm{mg} \mathrm{kg}^{-1}$ [2] and in topsoil for entire study area $220 \mathrm{mg} \mathrm{kg}^{-1}$ [3], it was found that in studied area the $\mathrm{Pb}$ average is 34-times higher than in the World, 36.1-times higher than European and 5.41-times higher than Macedonian (this region) averages. In regards to zinc where the average in World soils is $90 \mathrm{mg} \mathrm{kg}^{-1}$ [3], European topsoil $68 \mathrm{mg} \mathrm{kg}^{-1}$ [2] and an average in topsoil for the study area is 280 $\mathrm{mg} \mathrm{kg}^{-1}$ [3], it was found that in the studied area an average concentration of $\mathrm{Zn}$ is 19.7-times higher than World average, 26.1-times higher than European and 6.35-times higher than Macedonian average (for this region).

Similar to the previous two heavy metals $(\mathrm{Pb}, \mathrm{Zn})$ we analyzed cadmium geochemistry (World average $0.35 \mathrm{mg} \mathrm{kg}^{-1} \mathrm{Cd}$ [1], European average $0.12 \mathrm{mg} \mathrm{kg}^{-1}$ $\mathrm{Cd}$ [2], an average for the entire study area $7.7 \mathrm{mg} \mathrm{kg}$ $\left.{ }^{1} \mathrm{Cd}[3]\right)$, and we found that an average concentration of Cd was 120-times higher than the World average, 350-times higher than the European average and higher than Macedonian average (for this region) for 5.45-times.

In the very same manner copper had 2-times higher concentration than the World average of $30 \mathrm{mg}$ $\mathrm{kg}^{-1} \mathrm{Cu}, 3.53$-times higher than European average (17 $\mathrm{mg} \mathrm{kg}{ }^{-1} \mathrm{Cu}$ ) and 1.36-times higher than Macedonian average ( $44 \mathrm{mg} \mathrm{kg}^{-1} \mathrm{Cu}$ ), which matches findings by other researchers that very same year [3].

The group that comprises of $\mathrm{Cd}, \mathrm{Pb}$ and $\mathrm{Zn}$, as chemical elements that have been introduced into the environment through the anthropogenic activities [4], have shown the highest values in soils around the Veles smelting plant. That was expected even at the beginning of the study, but tremendously high values exceeded expectations. These findings illustratively are displayed at Figure 3.

Also, after detailed study it was determined that values from respective sampling points were spatially dependent. Namely, as can be seen from the plots and sampling location map, the lowest values were determined at topographically higher places than those for lower ones. This clarifies the correlation between pollution and smoke dust produced by the activity of former smelting plant in Veles.

The FENI smelting plant: The major source of anthropogenic environmental impact in the Tikvesh basin should be the FENI Industries's smelting plant (Figure 4), where environmental concern intensified due to fact that it is located in the hearth of the wellknown wine producing Tikveš region.

Plant has been operational since 1982 (produced $\sim 5000$ t of nickel metal annually), in 2005 it was acq- uired by Cunico Resources and steadily increased production to $16000 \mathrm{t}$ per year.

Soil sampling programme around the FENI plant took place at two separate localities, one on the NW of the smelting plant and the other one on the S-SE of the smelting plant. In both cases samples were taken along two parallel profiles and one perpendicular to them (Figure 4).

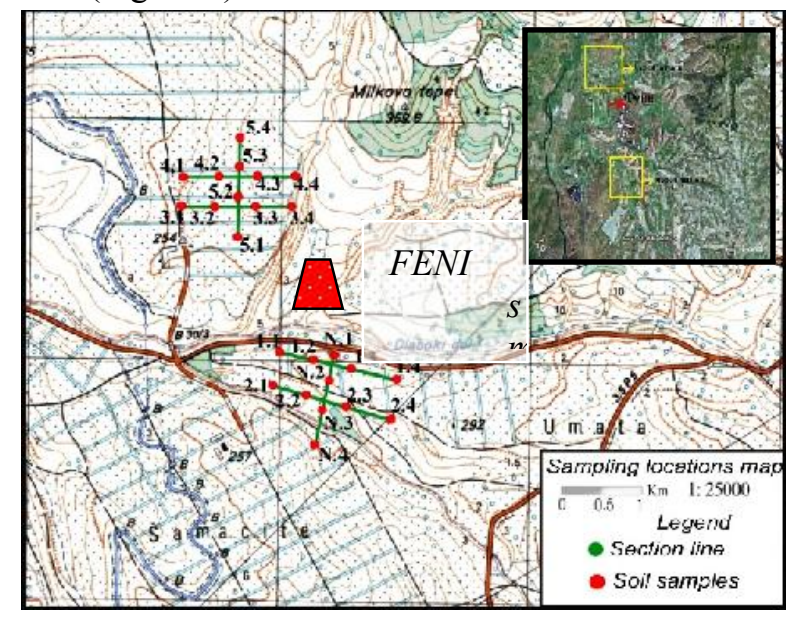

Figure 4 - Sampling locations around the FENI Industries smelting plant, small inset at the right upper corner gives the satellite position of the area.

Samples were analyzed to a standard array of heavy elements: $\mathrm{Pb}, \mathrm{Zn}, \mathrm{Cu}, \mathrm{Ni}, \mathrm{Fe}, \mathrm{Cr}, \mathrm{Co}$ and $\mathrm{Mn}$ (Table 2). Their concentrations were in the range as follows: $16 \div 31 \mathrm{mg} \cdot \mathrm{kg}^{-1} \mathrm{~Pb}, \quad 117 \div 286 \mathrm{mg} \cdot \mathrm{kg}^{-1} \mathrm{Zn}$, $13 \div 24 \mathrm{mg} \cdot \mathrm{kg}^{-1} \mathrm{Co}, \quad 42 \div 119 \mathrm{mg} \cdot \mathrm{kg}^{-1} \mathrm{Cu}, \quad 158 \div 292$ $\mathrm{mg} \cdot \mathrm{kg}^{-1} \mathrm{Ni}, 119 \div 236 \mathrm{mg} \cdot \mathrm{kg}^{-1} \mathrm{Cr}$ and $2.24 \div 3.79 \% \mathrm{Fe}$.

All of them were significantly above the reference values (Figure 5). Also, the calculated enrichment ratio (measured values over the reference value) speaks itself regarding the level of contamination.

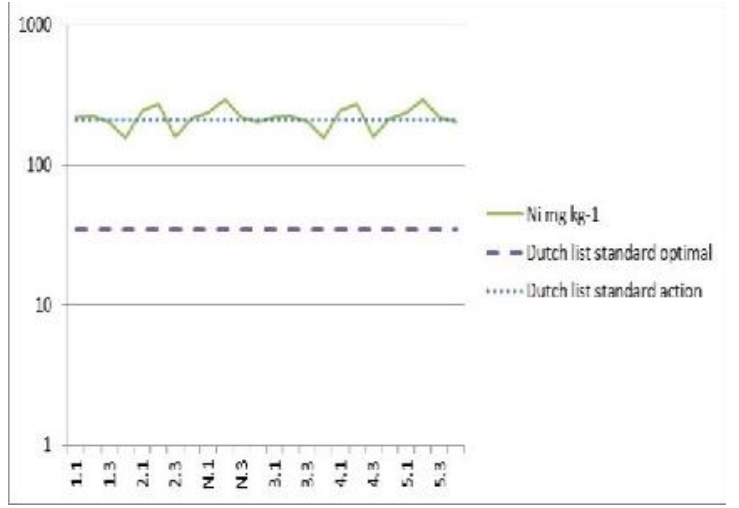

Figure 5 - Measured concentrations of $\mathrm{Ni}$ vs. standard values around the Feni-industries's smelting plant

Namely, the enrichment ratios ranged from relatively low 1.873 for $\mathrm{Fe}, 2.188$ for $\mathrm{Mn}$ and 3.801 for $\mathrm{Cu}$, through the medium 16.987 for $\mathrm{Ni}$ and 3.225 for $\mathrm{Zn}$ 
up to high 1.471 for $\mathrm{Pb}$ and the highest 2.823 for $\mathrm{Co}$ and 5.0124 for $\mathrm{Cr}$. These increased concentrations, bearing in mind the findings of $[5,6]$, probably can not be attributed solely to the anthropogenic input, since they were increased already due to geological composition.

It is probable that the FENI Industry plant, beside certain environmental impact, has not contributed extremely to measured values $[5,6,7,8]$.

Table 2. Concentrations of metals in soil samples from locations around the active smelting plant FENI in the vicinity of Kavadarci.

\begin{tabular}{|l|l|l|l|l|l|l|l|l|}
\hline Sample & $\mathrm{n}$ & Median & Min & max & $\begin{array}{l}\text { Dutch list } \\
\text { standard optim. }\end{array}$ & $\begin{array}{l}\text { Dutch list } \\
\text { standard action }\end{array}$ & $\begin{array}{l}\text { above } \\
\text { standard }\end{array}$ & $\begin{array}{l}\text { below } \\
\text { standard }\end{array}$ \\
\hline $\mathrm{Pb}\left(\mathrm{mg} \mathrm{kg}^{-1}\right)$ & 24 & 22 & 16 & 31 & 85 & 530 & 0 & 24 \\
\hline $\mathrm{Zn}\left(\mathrm{mg} \mathrm{kg}^{-1}\right)$ & 24 & 141 & 117 & 286 & 140 & 720 & 24 & 0 \\
\hline $\mathrm{Cu}\left(\mathrm{mg} \mathrm{kg}^{-1}\right)$ & 24 & 63,5 & 42 & 119 & 36 & 190 & 2 & 22 \\
\hline $\mathrm{Ni}\left(\mathrm{mg} \mathrm{kg}^{-1}\right)$ & 24 & 219,5 & 158 & 292 & 35 & 210 & 24 & 0 \\
\hline $\mathrm{Fe} \%$ & 24 & 3,46 & 2,24 & 3,79 & 1,8 & - & 0 & 24 \\
\hline $\mathrm{Ba}\left(\mathrm{mg} \mathrm{kg}^{-1}\right)$ & 23 & 151,5 & 0 & 223 & 160 & 625 & 23 & 0 \\
\hline $\mathrm{V}\left(\mathrm{mg} \mathrm{kg}^{-1}\right)$ & 24 & 47 & 24 & 75 & 42 & 250 & 0 & 24 \\
\hline $\mathrm{Cr}\left(\mathrm{mg} \mathrm{kg}^{-1}\right)$ & 24 & 187 & 119 & 236 & 100 & 380 & 24 & 0 \\
\hline $\mathrm{Co}\left(\mathrm{mg} \mathrm{kg}^{-1}\right)$ & 24 & 18 & 13 & 24 & 9 & 240 & 0 & 24 \\
\hline
\end{tabular}

The Zletovo Pb-Zn Deposit: Study of environmental impact of the Zletovo mine we have started with airborne dust produced during the primary crushing of ore, when it is released significant amount of dust that poses serious threat to the environment $[8,9,10]$. Analyzes displaying heavy metal concentrations in the dust averaged: $169 \mathrm{mg} \mathrm{kg}^{-1} \mathrm{As}, 86 \mathrm{mg} \mathrm{kg}^{-1} \mathrm{Cd}, 354$ $\mathrm{mg} \mathrm{kg}^{-1} \mathrm{Cu}, 10 \mathrm{mg} \mathrm{kg}^{-1} \mathrm{Ni}, 14800 \mathrm{mg} \mathrm{kg}^{-1} \mathrm{~Pb}$ and $16400 \mathrm{mg} \mathrm{kg} \mathrm{Kn}^{-1} \mathrm{Zn}$. All the measured values multiplexed above standard values, except nickel. Enrichment factors ranged from mediate ones such were those for copper of 20.8, cadmium of 28.7, arsenic of 32.5 up to high ones for zinc with 341.7 and lead 925. High concentration levels of heavy metals introduced by deposition from airborne dust and dispersion by wind, pose serious threat to an adjacent environment.

Soil sampling around the Zletovo mine was performed by other researchers but without any systematics and due to it was very hard to prepare complete review, which would reflect real situation regarding soil pollution [11]. We have decided to strengthen that knowledge and performed additional sampling (24 samples) in the vicinity of the Zletovo $\mathrm{Pb}-\mathrm{Zn}$ mine.

Namely, it was determined that representative elements are lead, zinc, iron and manganese and they are given in more details within this paper (Table 6), while elements such $\mathrm{Cr}, \mathrm{V}, \mathrm{Ni}$, Co have not displayed elevated concentrations (Table 3, Figure 6). An average amount of $\mathrm{Pb}$ in the world's soils is $35 \mathrm{mg}$ $\mathrm{kg}^{-1}$ [1], in the European topsoil is $33 \mathrm{mg} \mathrm{kg}^{-1}$ [2], in Macedonia (studied part) is $26 \mathrm{mg} \mathrm{kg}^{-1}$ [12]. As it is obvious from Table 3 , lead values ranged from the $42.30 \div 529.66 \mathrm{mg} \cdot \mathrm{kg}^{-1} \mathrm{~Pb}$, while the lowest values were determined near the Zletovo village the highest ones were determined in samples from localities Koritnica, Kiselica and Strmos.

In the main polluted area the average concentration of $\mathrm{Pb}$ is 8.6-times higher than the European $\mathrm{Pb}$ average and Macedonian average for 10.9-times. Although the average content of lead in the topsoil for the entire study area was found to be about $284.36 \mathrm{mg}$ $\mathrm{kg}^{-1}$, there are areas with increased concentration up to $529.66 \mathrm{mg} \mathrm{kg}^{-1}$, although even such values were not above action values by the Dutch list (Table 3; Figure 6).

The average amount of $\mathrm{Zn}$ in the world's soils is $90 \mathrm{mg} \mathrm{kg}^{-1}$ [1], in the European topsoil is $68 \mathrm{mg} \mathrm{kg}^{-1}$ [2], in Macedonia (studied part) is $55 \mathrm{mg} \mathrm{kg}^{-1}$ [12]. The highest concentrations of zinc were determined near the Koritnica, Kiselica and Ziganci while the whole range was quite wide starting from $138 \mathrm{mg} \cdot \mathrm{kg}^{-}$ ${ }^{1} \mathrm{Zn}$ and ending up to $3240 \mathrm{mg} \cdot \mathrm{kg}^{-1} \mathrm{Zn}$. For the main 
polluted area, the average concentration of $\mathrm{Zn}$ is 19.2times higher than the European $\mathrm{Zn}$ average and Macedonian average for 23.7-times. Similarly to the findings for lead, although the average content of zinc

Table 3. Concentrations of particular heavy metals in soil samples from the vicinity of the Zletovo Mine, Macedonia

\begin{tabular}{|l|l|l|l|l|l|l|l|l|}
\hline Sample & $\mathrm{n}$ & $\min$ & $\max$ & average & $\begin{array}{l}\text { Dutch list } \\
\text { (Optimum) }\end{array}$ & $\begin{array}{l}\text { Dutch list } \\
\text { (Action) }\end{array}$ & $\begin{array}{l}\text { Above } \\
\text { optimum }\end{array}$ & $\begin{array}{l}\text { Above } \\
\text { action }\end{array}$ \\
\hline $\mathrm{Pb}(\mathrm{mg} \mathrm{kg}-1)$ & 24 & 42,3 & 529,66 & 266,5442 & 85 & 530 & 23 & 0 \\
\hline $\mathrm{Zn}(\mathrm{mg} \mathrm{kg}-1)$ & 24 & 138 & 3240 & 1180,333 & 140 & 720 & 23 & 14 \\
\hline $\mathrm{Fe}$ (g kg-1) & 24 & 19.3 & 76.9 & 38.70 & 18 & 72 & 24 & 1 \\
\hline $\mathrm{Mn}$ (mg kg-1) & 24 & 643 & 28000 & 6707,583 & 33 & 330 & 24 & 24 \\
\hline
\end{tabular}

The average amount of $\mathrm{Fe}$ in the world's soils is $35 \mathrm{~g} \mathrm{~kg}^{-1}$ [1], in the European topsoil is $21.7 \mathrm{~g} \mathrm{~kg}^{-1}$ [2], in Macedonia in the considered area is $33 \mathrm{~g} \mathrm{~kg}^{-1}$

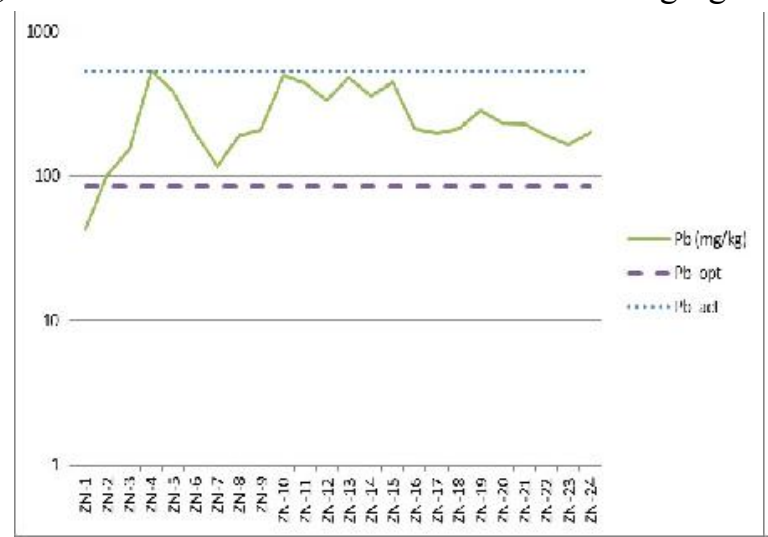

a) in the topsoil for the entire study area was found to be about $1303.5 \mathrm{mg} \mathrm{kg}^{-1}$, there are areas with very high level of contamination (Table 3; Figure 6).

[12]. As it is obvious from the table above (Table 3), we would like to stress out that iron values ranged from the $19.3 \div 76.9 \mathrm{~g} \cdot \mathrm{kg}^{-1} \mathrm{Fe}$.

1000

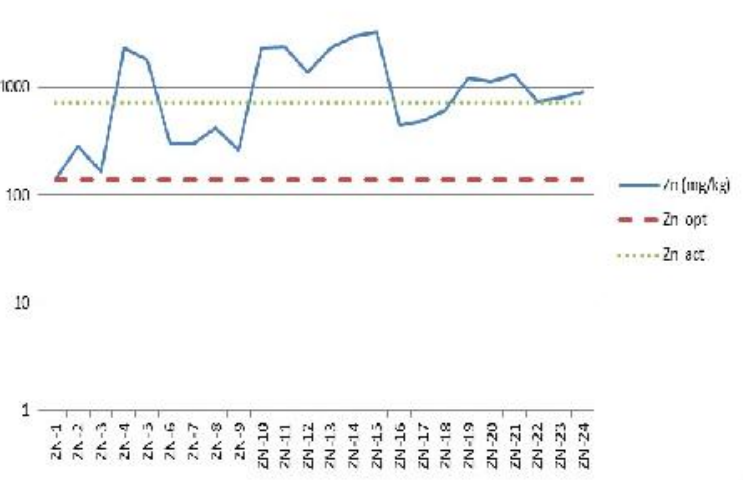

b)

Figure 6 - Measured concentrations of some heavy metals (Pb and $\mathrm{Zn}$ ) vs. Dutch standard in soils around the Zletovo Mine, Macedonia. (Note: all plots have logarithmic vertical scale)

Either the iron haven't shown significantly increased values, the highest ones were recorded for the locations such as Kiselica, Koritnica and Strmos. In the main polluted area the average concentration of $\mathrm{Fe}$ is 1.9-times higher than the European Fe average and Macedonian average for 1.2-times. Although the average content of iron in the topsoil for the entire study area was found to be about $40.67 \mathrm{~g} \mathrm{~kg}^{-1}$, there are areas with increased concentration up to $76.9 \mathrm{~g}$ $\mathrm{kg}^{-1}$, although only one value was above action value by the Dutch list.

On the World scale, the range of Mn average contents was calculated at $488 \mathrm{mg} \mathrm{kg}^{-1}$, while for the US soils it is $495 \mathrm{mg} / \mathrm{kg}$ [13], in European topsoil is $382 \mathrm{mg} \mathrm{kg}^{-1}$ [2], and in Macedonia in the considered area is averages $650 \mathrm{mg} \mathrm{kg}{ }^{-1}$ [12]. Manganese analyses around the Zletovo mine area have shown the highest concentrations among analyzed elements, ranging from 643 up to $28000 \mathrm{mg} \mathrm{kg}^{-1} \mathrm{Mn}$. In the main polluted area the average concentration of $\mathrm{Mn}$ is 14.9-times higher than the European $\mathrm{Pb}$ average and Macedonian average for 11.9-times. Although the average content of $\mathrm{Mn}$ in the the entire study area was found to be about $7791.75 \mathrm{mg} \mathrm{kg}^{-1}$, there are areas with increased concentration up to $28000 \mathrm{mg} \mathrm{kg}^{-1}$, however all the measured values were above action value by the Dutch list (Table 3). Here we are dealing with anthropogenic input in soils around the Zletovo mine, which clearly indicates their connection with the processing of lead-zinc ore from the mine.

The Buchim $\mathrm{Cu}$ Deposit: The only one active copper mine within the Macedonia was enclosed in ours environmental study. Considering airborne dust pollution we would like to stress out that the studies on this subject already exists $[14,15,16]$, so we used them as representative ones, while interesting $\mathrm{Cu}$ and other elements anomalies in soils were given by [8, 17]. Our results, performed on 25 samples from 25 locations including minimal, maximal, average and referent values according to the New Dutchlist (www.contaminatedland.co.uk/std-guid/dutch-1.htm) are shown at Table 4. Distribution of some pollutants is shown at Figure $7 \mathrm{a}, \mathrm{b}$. These results are in agreement with those obtained by [18] from the study of soil pollution in the wider region of Radoviš and its environ where $\mathrm{As}, \mathrm{Cu}, \mathrm{Pb}, \mathrm{V}$ and $\mathrm{Zn}$ were determined as 
anthropogenetic elements due to the mining and ore processing at the Buchim plant. That is especially accented in the eastern and southwestern parts of the main polluted area around flotation. High contents of $\mathrm{Cu}$ and $\mathrm{Pb}$ are not only due to mining works, but also the town works, traffic, industry and developed technological processes which emited higher amounts of these heavy metals in air $[14,15,16,18,19,20$, 21]. An average amount of arsenic in the World's soils of $5 \mathrm{mg} \mathrm{kg}^{-1}$ [1], and European of $12 \mathrm{mg} \mathrm{kg}^{-1}$ [2] has been overcome within entire study area, ranging 13.1-225 mg kg-1 (average $63.904 \mathrm{mg} \mathrm{kg}^{-1}$; Table 4 and Figure 7a). In several anomalous areas it could be seen that the highest values are in the area closest to the outflow of flotation dam (from 51 to $225 \mathrm{mg} \mathrm{kg}^{-1}$ ) and so-called Buchim Lake and dry riverbed draining open pit mine and in the south-western part of the area $\left(67.4-82.8 \mathrm{mg} \mathrm{kg}^{-1}\right)$.

Table 4. Statistical data from the soil samples around the Buchim copper mine

\begin{tabular}{|l|l|l|l|l|c|c|c|c|}
\hline Element & $\mathrm{n}$ & $\min$ & $\max$ & Average & $\begin{array}{c}\text { Optimum } \\
\text { (Dutch list) }\end{array}$ & $\begin{array}{c}\text { Action (Dutch } \\
\text { list) }\end{array}$ & $\begin{array}{c}\text { Above } \\
\text { optimum }\end{array}$ & $\begin{array}{c}\text { Above } \\
\text { action }\end{array}$ \\
\hline $\mathrm{Al}(\%)$ & 25 & 0.72 & 5.90 & 2.89 & 4.7 & - & 5 & 0 \\
\hline $\mathrm{Fe}(\%)$ & 25 & 0.73 & 5.02 & 3.15 & 1.8 & & 21 & 0 \\
\hline $\mathrm{As}\left(\mathrm{mg} \mathrm{kg}^{-1}\right)$ & 25 & 13.1 & 225 & 63.9 & 29 & 55 & 20 & 7 \\
\hline $\mathrm{Cd}\left(\mathrm{mg} \mathrm{kg}^{-1}\right)$ & 25 & 0.67 & 17.9 & 2.19 & 0.8 & 12 & 17 & 1 \\
\hline $\mathrm{Co}\left(\mathrm{mg} \mathrm{kg}^{-1}\right)$ & 25 & 3.62 & 22.3 & 12.4 & 9 & 240 & 22 & 0 \\
\hline $\mathrm{Cr}\left(\mathrm{m} \mathrm{kg} \mathrm{k}^{-1}\right)$ & 25 & 30.1 & 171 & 80.7 & 100 & 380 & 6 & 0 \\
\hline $\mathrm{Cu}\left(\mathrm{mg} \mathrm{kg}^{-1}\right)$ & 25 & 17.8 & 1734 & 129 & 36 & 190 & 16 & 3 \\
\hline $\mathrm{Mn}\left(\mathrm{mg} \mathrm{kg}^{-1}\right)$ & 25 & 165 & 998 & 552 & 33 & - & 25 & 0 \\
\hline $\mathrm{Ni}\left(\mathrm{mg} \mathrm{kg}^{-1}\right)$ & 25 & 9.8 & 69.4 & 29.5 & 35 & 210 & 5 & 0 \\
\hline $\mathrm{Pb}\left(\mathrm{mg} \mathrm{kg}^{-1}\right)$ & 25 & 46 & 3465 & 288 & 85 & 530 & 19 & 1 \\
\hline $\mathrm{Sr}\left(\mathrm{mg} \mathrm{kg}^{-1}\right)$ & 25 & 17.6 & 132 & 75.8 & - & - & 0 & 0 \\
\hline $\mathrm{V}\left(\mathrm{mg} \mathrm{kg}^{-1}\right)$ & 25 & 14 & 144 & 83.6 & 42 & 250 & 22 & 0 \\
\hline $\mathrm{Zn}\left(\mathrm{mg} \mathrm{kg}^{-1}\right)$ & 25 & 88 & 3438 & 320 & 140 & 720 & 12 & 1 \\
\hline
\end{tabular}

According to this, it is evident that the source of high arsenic in this region is directly related to processing of copper ores in the Buchim Mine. During the processing of ore, probably one part of

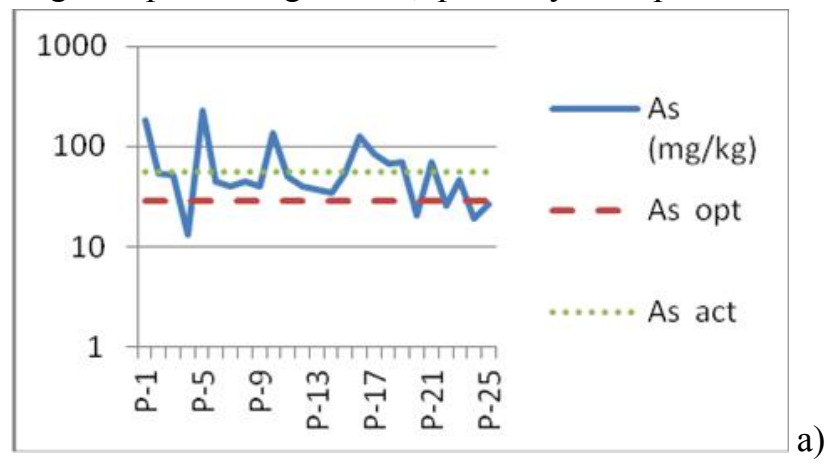

that arsenic have been released and distributed into the adjacent environment.

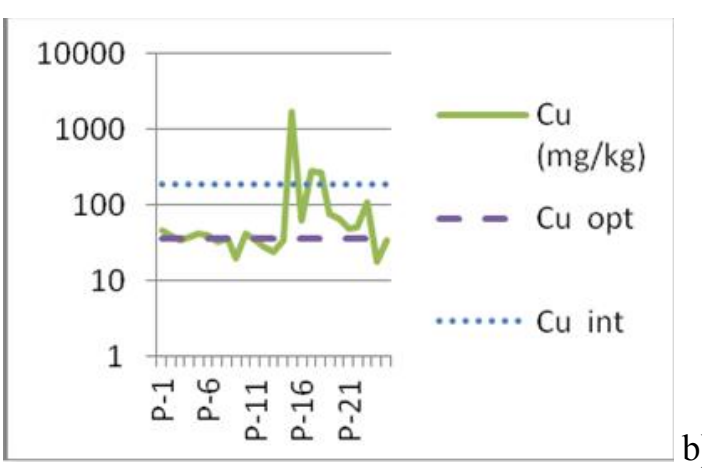

Figure 7 - a) Diagram of arsenic distribution in the soil compared with optimal and action values; b) Diagram of copper distribution in the soil compared with optimal and action values

The cadmium range of $0.67-17.9 \mathrm{mg} \mathrm{kg}^{-1}$ (averaging $2.19 \mathrm{mg} \mathrm{kg}^{-1}$ ) in the topsoil for the entire study area significantly overcome $\mathrm{Cd}$ in soils in the World of $0.35 \mathrm{mg} \mathrm{kg}^{-1}$ [1] and in European topsoil of 0.12 $\mathrm{mg} \mathrm{kg}^{-1}$ [2]. The average concentration of $\mathrm{Cd}$ is more than 18-times higher than the European cadmium average and up to $7.5-13$ times more than Macedonian average of $0.16 \mathrm{mg} \mathrm{kg}^{-1}$ (study in 2002, see [22]) and $0.29 \mathrm{mg} \mathrm{kg}^{-1}$ (study in 2005, see [23]). Cadmium concentrations were very high in the topsoils from the copper mine facilities and flotation dam vicinity. These higher contents are the result of anthropogenic origin where cadmium was introduced by mine industrial complexes as it was confirmed elsewhere [24].

Soil contamination by $\mathrm{Cu}$ compounds displayed the highest increased levels around $\mathrm{Cu}$ mines and smelters [25]. As $\mathrm{Cu}$ is only slightly mobile under most soil conditions elevated contents may persist for a long time. The average amount of $\mathrm{Cu}$ in the world's soils is $30 \mathrm{mg} \mathrm{kg}^{-1}$ [1], in the European topsoil is 17 $\mathrm{mg} \mathrm{kg}{ }^{-1}$ [2] and in Macedonia is $31.8 \mathrm{mg} \mathrm{kg}^{-1}$ [19]. 
The average amount of $\mathrm{Cu}$ in the topsoil for the entire study area is $129.064 \mathrm{mg} \mathrm{kg}^{-1}$, with a range of 17.8 $1734 \mathrm{mg} \mathrm{kg}^{-1}$ (Table 4; Figure 7b). In the main polluted area, the average concentration of $\mathrm{Cu}$ exceeds the European $\mathrm{Cu}$ average by a factor of 15.3 and Macedonian average for 8.2-times. The highest content of copper is present in topsoils from areas of the copper mine drainage dry riverbed close to the mine.

The average amount of $\mathrm{Pb}$ in the world's soils of $35 \mathrm{mg} \mathrm{kg}^{-1}$ [1], in European topsoil is $33 \mathrm{mg} \mathrm{kg}^{-1}$ [2] and in Macedonian is $44.3 \mathrm{mg} \mathrm{kg}^{-1}$ [19] was overcome for the entire study area with an average of $288 \mathrm{mg} / \mathrm{kg}$ (range of 46-3465 mg kg-1 , Table 4).

The average amount of $\mathrm{Zn}$ in the world's soils is $90 \mathrm{mg} \mathrm{kg}^{-1}[1,13]$, in the European topsoil is $68 \mathrm{mg}$ $\mathrm{kg}^{-1}$ [2] and in Macedonia is $31.8 \mathrm{mg} \mathrm{kg}^{-1}$ [19]. The average $\mathrm{Zn}$ amount in the topsoil for the entire study area is $319.8 \mathrm{mg} \mathrm{kg}^{-1}$, with a range of $88-3438 \mathrm{mg} \mathrm{kg}^{-}$ ${ }^{1}$ (Table 4). Similarly to the findings for lead, there are areas with very high level of contamination (Table 4), although all high $\mathrm{Cu}$ and $\mathrm{Pb}$ contents can not be attributed to mining works, but also can be due to traffic, industry and other processes which aloud emission of higher amounts of these heavy metals $[6$, $14,15,16,20,21]$.

\section{CONCLUSION}

The results of this study have shown that at all the localities are characterized by increased values of pollutant heavy metals in soil, which can be attributed to the anthropoghenic influx around the aforementioned mines and related processing facilities. Pollution halo diameter around them sometimes reaches over $20 \mathrm{~km}$. Along common pollutants $(\mathrm{Pb}, \mathrm{Zn}, \mathrm{Cd})$ around Zletovo mine at lead-zinc and Veles smelting were determined increased concentrations of $\mathrm{As}, \mathrm{Ag}, \mathrm{W}, \mathrm{Ni}, \mathrm{Co}$ etc., while around the FENI smelting along to $\mathrm{Fe}$ and $\mathrm{Ni}$ were determined increased values of $\mathrm{Cr}, \mathrm{V}, \mathrm{Co}$, $\mathrm{Mn}$ etc. Increased concentrations, as expected, of $\mathrm{Cu}$, $\mathrm{As}, \mathrm{Pb}, \mathrm{Zn}$ and $\mathrm{Cd}$ were determined around the Buchim mine.

\section{REFERENCES}

[1] Bowen, H. M., Environmental Chemistry of the Elements. Academic Press, New York, - pp. 333, 1979.

[2] Salminen, R., Batista, M.J., Bidovec, M., Demetriades, A., De Vivo, B., De Vos, W., Duris, M., Gilucis, A., Gregorauskiene, V., Halamic, J., Heitzmann, P., Jordan, G., Klaver, G., Klein, P., Lis, J., Locutura, J., Marsina, K., Mazreku, A., O'Connor, P.J., Olsson, S. A., Ottesen, R.T., Petersell, V., Plant, J.A., Reeder, S., Salpeteur, I., Sandstrom, H., Siewers, U., Steenfelt, A. and Tarvainen T., Geochemical Atlas of Europe. Part 1, Background information, methodology and maps. Geological Survey of Finland, Espoo, 2005, 526 p.
[3] Stafilov, T., Šajn, R., Pančevski, Z., Boev, B., Frontasyeva, V. M. and Strelkova, P. L., Geochemical atlas of Veles and the environs.Faculty of Natural Sciences and Mathematics-Skopje, University "Sts. Cyril and Methodius"-Skopje, 2008, 123 p.

[4] Stafilov, T., Šajn R., Pančevski Z., Boev B., Frontasyeva V. M., Strelkova P. L., Heavy metal contamination of topsoils around a lead and zinc smelter in the Republic of Macedonia. Journal of Hazardous Materials, 175, 896-914, 2010.

[5] Stafilov, T., Šajn, R., Boev, B., Cvetković, J., Mukaetov, D., Andreevski, M., Geochemical atlas of Kavadarci and the environs.Faculty of Natural Sciences and Mathematics-Skopje, University "Sts. Cyril and Methodius"-Skopje, 2008, 109 p.

[6] Stafilov, T., Šajn R., Boev B., Cvetković J., Mukaetov D., Andreevski M., Lepitkova S., Distribution of some elements in surface soil over the Kavadarci Region, Republic of Macedonia, Environmental Earth Sciences, 61, 1515-1530, 2010.

[7] Serafimovski, T., Dolenec, T., Tasev, G.,RoganŠmuc, N., Dolenec, M. and Vrhovnik, P., Particular Macedonian Tertiary basins: geological features and anthropogenic input. Proceedings of the $2^{\text {nd }}$ Workshop on the UNESCO-IGCP Project "Anthropogenic effects on the human environment in the Neogene basins in the SE Europe", Eds. Bermanec \& Serafimovski, Zagreb, Croatia, pp. 43-60, 2011.

[8] Serafimovski, T., Dolenec, T., Tasev, G., RoganŠmuc, N., Dolenec, M. and Vrhovnik, P., Pollution Related With Active Mines In The Eastern Macedonia. Proceedings of the $3^{\text {rd }}$ Workshop on the UNESCO-IGCP Project "Anthropogenic effects on the human environment in the Neogene basins in the SE Europe", Eds. T. Dolenec \& T. Serafimovski, Ljubljana, Slovenia, pp. 43-60, 2011.

[9] Walton, C., Philips, D., Serafimovski, T., Siderovski, K., Georgieva, M. and Ivanov, F., Environmental Audit Report, Zletovo Mine. Adam Smith Institute and Ministry of Environment and Physical Planing of the Republic of Macedonia. 2003, $41 \mathrm{p}$.

[10] Tasev, G. and Serafimovski, T., Pollution Around The Zletovo Mine, Republic of Macedonia. Proceedings, $2^{\text {nd }}$ Workshop UNESCO-IGCP Project "Anthropogenic effects on the human environment in the Neogene basins in the SE Europe", Eds. Bermanec \& Serafimovski, Zagreb, Croatia, pp. 79-86, 2011.

[11] Sijakova-Ivanova, T. and Paneva-Zajkova, V., Trace elements in the soils in the vicinity of the village of Pisica. (Ed: Boev, B. and Serafimovski, T) $3^{\text {rd }}$ International Workshop on the UNESCO-IGCP Project: Anthropogenic effects on the human environment in Tertiary basins in the Mediterranean, Stip, $21^{\text {st }}$ October 2005, pp. 77-80, 2005.

[12] Stafilov, T., Balabanova, B. and Šajn, R., Geochemical atlas of the region of the Bregalnica River ba- 
sin. Faculty of Natural Sciences and MathematicsSkopje, 2014, 172 p.

[13] Prasad, A. S., Zinc: An Overview. Nutrition, 11, 93-99, 1995.

[14] Balabanova, B., Stafilov T., Šajn R., Bačeva K., Distribution of chemical elements in attic dust as reflection of their geogenic and anthropogenic sources in the vicinity of the copper mine and flotation plant, Archive of Environmental Contamination and Toxicology, 61, 173-184, 2011.

[15] Balabanova, B., Stafilov T., Šajn R., Bačeva K., Total deposited dust as a reflection of heavy metals distribution in area with intensively exploited copper minerals, Geologica Macedonica, 25, 1-9, 2011.

[16] Balabanova, B., Stafilov, T., Šajn, R. and Bačeva, K., Monitoring deposition of anthropogenic introduced elements in air. case study: copper mine environ. $2^{\text {nd }}$ International Workshop UNESCO-IGCP Project: "Anthropogenic effects on the human environment in the Neogene basins in the SE Europe", pp 67-72, 2011.

[17] Stojanovska, M., Distribution of heavy and toxic metals in water, sediment and soil in the vicinity of Buchim mine. Bachelor thesis, Faculty of Mining and Geology, Stip, University "Sts. Cyril and Methodius"-Skopje, 2005, 159 p. (in Macedonian)

[18] Balabanova, B., Stafilov T., Šajn R., Bačeva K., Spatial distribution and characterization of some toxic metals and lithogenic elements in topsoil and subsoil from copper mine environs, International Journal of Environmental Protection, 3, 1-9, 2013.

[19] Stafilov, T., Balabanova B., Šajn R. Bačeva K., Boev B., Geochemical Atlas of Radoviš and the Environs and the Distribution of Heavy Metals in the
Air, Faculty of Natural Sciences and Mathematics, Skopje, 2010, 90 p.

[20] Balabanova B., Stafilov T., Bačeva K., Šajn R., Atmospheric pollution with copper around the copper mine and flotation, Bučim, Republic of Macedonia, using biomonitoring moss and lichen technique, Geologica Macedonica, 23, 35-41, 2009.

[21] Balabanova B., Stafilov T., Bačeva K., Šajn R., Biomonitoring of atmospheric pollution with heavy metals in the copper mine vicinity located near Radoviš, Republıc of Macedonıa, Journal of Environmental Science and Health, Part A, Toxic/Hazardous Substance \& Environmental Engineering, 45, 1504-1518, 2010.

[22] Barandovski, L., Cekova M., Frontasyeva M. V., Pavlov S. S., Stafilov T., Steinnes E., Urumov, V. Atmospheric Deposition of Trace Element Pollutants in Macedonia Studied by the Moss Biomonitoring Technique, Environmental Monitoring and Assessment, 138, 107-118, 2008.

[23] Barandovski, L., Frontasyeva M. V., Stafilov T., Šajn R., Pavlov S., Enimiteva V., Trends of atmospheric deposition of trace elements in Macedonia studied by the moss biomonitoring technique, Journal of Environmental Science and Health, Part A., 47, pp 2000-2015, 2012.

[24] Šajn, R., Halamić J., Peh Z., Galović L., Alijagić J., Assessment of the natural and anthropogenic sources of chemical elements in alluvial soils from the Drava River using multivariate statistical methods, Journal of Geochemical Exploration, 110, pp 278-289, 2011.

[25] Kabata-Pendias, A., Pendias H., Trace Elements in Soil and Plants, $3^{\text {rd }}$ ed.; CRC Press, 2001.

\section{REZIME}

\section{KONTAMINACIJA ZEMLJIŠTA U OKOLINI NEKIH AKTIVNIH I ZATVORENIH RUDNIČKIH POSTROJENJA U REPUBLICI MAKEDONIJI}

Nekoliko industrijskih izvora kontaminacije na teritoriji Republike Makedonije, su proučeni, jedan rudnik olova i cinka sa flotacijom, jedan rudnik bakra sa flotacijom i postrojenjem za luženje bakra, kao i jedno staro Pb-Zn topioničko postrojenje u blizini Velesa $i$ jedno $\mathrm{Fe}-\mathrm{Ni}$ topioničko postrojenje $u$ blizini

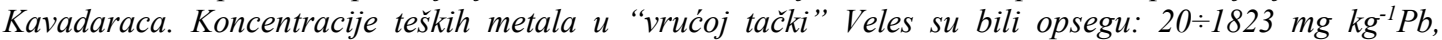

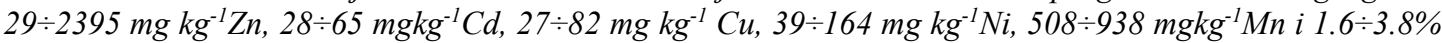
Fe, pri čemu su svi bili iznad optimalnih vrednosti od prema Holandskog standarda. U blizini fabrike Feni koncentracije teških metala su bile kao što je prikazano: $16 \div 31 \mathrm{mg} \mathrm{kg}^{-1} \mathrm{~Pb}, 117 \div 286 \mathrm{mgkg}^{-1} \mathrm{Zn}_{1} 13 \div 24 \mathrm{mg}$ $\mathrm{kg}^{-1} \mathrm{Co}, 42 \div 119 \mathrm{mg} \mathrm{kg}^{-1} \mathrm{Cu}, 158 \div 292 \mathrm{mg} \mathrm{kg}^{-1} \mathrm{Ni}, 119 \div 236 \mathrm{mg} \mathrm{kg}^{-1} \mathrm{Cr}$ i $2.24 \div 3.79 \% \mathrm{Fe}$. Merenja prašine u vazduhu oko rudnika Zletovo su pokazala povećane vrednosti, nekoliko puta iznad standardnih, osim nikla, a faktori obogaćivanja su se kretali od srednjih, kao što su bili oni za bakar od 20.8, kadmijum 28.7, arsen of 32.5 pa sve do visokih za cink od 341.7 i olovo 925. Uzorci zemljišta iz okoline rudnika Zletovo su pokazali sledeće koncentracije: $19.3-76.9 \mathrm{~g} \mathrm{~kg}^{-1} \mathrm{Fe}, 643-28000 \mathrm{mg} \mathrm{kg}^{-1} \mathrm{Mn}$, 42.3-529.66 mg kg-1 $\mathrm{Pb}$ i 138 $3240 \mathrm{mg} \mathrm{kg}^{-1} \mathrm{Zn}$. Na kraju u okolini rudnika bakra Bučim rezultati su pokazali sledeće koncentracije: $13.1 \div 225 \mathrm{mg} \mathrm{kg}^{-1} \mathrm{As}, 0.67 \div 17.9 \mathrm{mg} \mathrm{kg}^{-1} \mathrm{Cd}, 30.1 \div 171 \mathrm{mg} \mathrm{kg}^{-1} \mathrm{Cr}, 17.8 \div 1734 \mathrm{mg} \mathrm{kg}^{-1} \mathrm{Cu}, 9.8 \div 69.4 \mathrm{mg} \mathrm{kg}^{-1}$ $\mathrm{Ni}, 46 \div 3456 \mathrm{mg} \mathrm{kg}^{-1} \mathrm{~Pb}, 88 \div 3438 \mathrm{mg} \mathrm{kg}^{-1} \mathrm{Zn}, 169 \div 998 \mathrm{mg} \mathrm{kg}^{-1} \mathrm{Mn} \mathrm{i} 0.73 \div 5.02 \% \mathrm{Fe}$.

Ključne reči: teški metali, kontaminacija, rudnici, antropogeno, R. Makedonija 